\title{
LIKE-FOR-LIKE AND COMPATIBLE MORTARS FOR THE REPAIR OF TRADITIONAL BUILDINGS
}

\author{
Nigel Copsey $1, *$ \\ ${ }^{1}$ Stonemason, building conservator, Research Associate, Dept of Archaeology, University of York. \\ Hall Farm, Maltongate, Thornton Dale, North Yorkshire, YO18 7SA, UK - nigelcopsey@ hotmail.com
}

Commission II - WG II/8

KEYWORDS: Earth-lime, Hot mixed air lime, Natural hydraulic lime, Like-for-like, Compatible, Effective porosity

\begin{abstract}
:
The subject of this paper is traditional mortar preparation and materials, particularly earth-lime and air or feebly hydraulic hot mixed lime mortars with particular emphasis upon British practice and experience, whilst stressing their international ubiquity historically. It will demonstrate their appropriate functional performance and attest to the need to use similar mortars, similarly composed and prepared, in the repair and conservation of traditionally constructed buildings. It will question how commonly modern Natural Hydraulic Limes may be considered to be like-for-like or of compatible strength and functional performance. The paper will draw upon extensive research into historic texts, as well as primary archive research into historic building accounts and the latest research into the properties of lime rich air lime mortars and NHL mortars.
\end{abstract}

\section{INTRODUCTION}

The technical evidence does not point to short cuts in the achievement of good building; it points consistently to the discovery by scientific means of the rationale of established building traditions, which should be altered only with the full knowledge of the consequences... (RIBA Committee, 1946, p. 5)

It may be reasonably stated that earth-lime and hot mixed pure or nearly pure lime mortars represent the ubiquitous mortars of traditional construction (Copsey, 2019a, 2019b, 2019c, 2019d), along with clay-bearing sub-soil itself. They might be used alone, discreetly, or - as was generally the case over much of time - in combination. Earth-lime mortars were used for monolithic building, but also as a bedding mortar, and as a base-coat plaster mortar in masonry and timber-frame construction. In both cases, such mortars were overlaid with a hot mixed pure lime or pure lime and aggregate pointing mortar, or - over earth-lime backing coats - with a similarly pure lime or minimally aggregated plaster mortar, generally with ample addition of animal hair - sometimes of dried grasses - to resist shrinkage and offer flexural strength. Inside and out, such earth-lime systems were completed by the application of earth-lime (with more lime added) or pure or feebly hydraulic lime render coats and limewashes; as a minimum, with limewash only. The pattern was very similar when hot mixed lime: sand (or stonedust or brickdust) mortars were used, although the precise recipes for bedding and base-coat plaster coats might vary somewhat from pointing in the initial absence of exterior renders, being frequently richer in lime or with small volumes of added pozzolan, such as wood ash or brick.

Earth-lime, and lime: sand mortars were typically made with quicklime and were mixed hot, as soon as the quicklime had substantially slaked, or, indeed, as the slake proceeded, although either might also be made using quicklime initially slaked on its own to a dry hydrate or to a thick paste, and earth-lime mortars were generally - although not always - significantly leaner in lime than were those made with sand or other aggregate, whether this was pozzolanic or essentially inert. The binder of an earth-lime mortar was both clay and lime in combination and its set developed by both simple drying (by suction from porous materials as well as by air movement) and by a 'pseudo-pozzolanic' reaction - in fact an ion-exchange (Minke, 2006) - between the lime and the clay. Unlike an air lime mortar, the setting of an earth-lime mortar relies far more upon this reaction than upon carbonation (Boynton, 1980), hence its still common use in road-soil stabilisation, providing a firmly consolidated base-layer after the addition of only $3 \%$ of quicklime to a clay-bearing subsoil. That such reaction takes place is indicated by the significantly greater strengthening effect of quicklime compared to similar additions of either Portland cement or NHL, $4 \%$ quicklime addition offering $25 \%$ more $\mathrm{MPa}$ than a similar volume of Portland cement to the same sub-soil, as well as greater durability (Eires, 2013). Over the last five years, Historic England and Historic Environment Scotland (HES) have reasserted their commitment to like-for-like repair and have commissioned extensive research into traditional mortars, engaging far more critically with the almost default specification of natural hydraulic limes, the use of which HES, at least, will no longer support, except as a gauge into air lime mortars. HE research projects into the character and performance of pozzolanic air lime and hot mixed lime mortars, as well as slaking mechanics, are in train and HES have published five out of six Technical Papers focused upon hot mixed lime mortars.

\section{TRADITIONAL MORTARS AND THEIR PRIMARY USES}

The vast majority of stone buildings - of all status - built before around 1800 in the UK were built using earth-lime mortars finished with pure or nearly pure lime mortars and, typically with renders and/or limewash (Copsey, 2019a, 2019c). Likewise in France and across Europe; likewise in China (Shi Bing, 2013, 2019), continuing later than in the UK, where enclosure of previously common lands largely deprived communities of ready access to the necessary sub-soils and where lime-sand mortars came to dominate throughout the 19 thC, when some 6 million

\footnotetext{
* Corresponding author
} 
dwellings and many civic and industrial structures were constructed on an unprecedented scale (Powell, 1980), having previously been reserved for some larger buildings, such as fortresses and some - but by no means all - higher status structures. Lime-sand was always an option, but earth-lime mortars shared with it similar characteristics of workability, cohesiveness and adhesiveness as well as offering similarly excellent water retentivity and subsequent bond. Both mortars offered optimal capillarity to evacuate received moisture, whilst at the same time possessing a tenacity and composition that resisted excessive water penetration. Both contained high proportions of inter-connected pores of around 1 micron (Faria, 2016; Wiggins, 2019), optimal for the capillary movement of liquid-phase water. Both exhibited compressive strengths of typically - between 0.8 and $2 \mathrm{MPa}$ (Figueiredo, 2018; Rashmi 2014, Henry et al., 2018). Both set slowly but steadily over a period of months or even years, but both became load-bearing within minutes of placement and were resistant to 'squeeze', increasing build efficiency, and remained deformable during early settlement. To stonemasons, bricklayers and plasterers, these characteristics were essential, as was efficiency of preparation and ease of use and, of course, cost. Quicklime and sub-soil, and sand, where this was readily available, were of lower cost; they allowed for swift and efficient mixing and required less handling or storage - in most cases, they were mixed and used, either immediately, whilst the heat of the slake remained, or soon after cooling and generally within days of preparation, after a modicum of re-tempering, although there were always those who preferred a longer period of repose after initial hot mixing. Any given volume of air quicklime carried to site offered twice that same volume as binder, after slaking; hydraulic quicklime expanded much less, and less and less as its hydraulic power increased and its free lime content diminished. 'Lean' limes with high volumes of inert clay were similarly less expansive on slaking and prone to late-slaking after placement, and were typically of feeble hydraulicity. They were generally disliked by masons (Searle, 1935).

Sometimes, the workers reject types of lime which would be preferable to the ones they are accustomed to using. Thus, in the region of Calvados, half of the limekilns produce hydraulic lime for the consumption of farmers to enrich their fields whereas this same lime is not at all used by the masons, because it does not expand as much as the others and because it hardens quickly, therefore the workers would have to change how they work... (Biston, 1828, p. 203-204)

Previously slaked lime, in the form of a dry or a wet hydrate, was, of course, always used as well, but lime putty was rarely used as a binder before the 20thC (and was distrusted and considered inherently weak in its binding qualities (Wright, 1845), but was commonly used on its own as a mortar - for finely jointed stone ashlar; for finely jointed brickwork and for fine plaster finish coats - or, for more than fine finish coats (with ample hair addition) over earthen, or earth-lime-bound substrates. Such finishes might be between 4 and $8 \mathrm{~mm}$ thick. The primary purpose of running quicklime to lime putty (typically of a 'bread-dough' consistency, not a slurry) was to remove the inevitable residues of unslaked or imperfectly slaked lime, allowing time for this to proceed, since their presence would be a nuisance or an impediment in the finest joints or upon the finest surfaces - during application and because of the risk of late-slaking disrupting a perfectly finished plaster scheme. Lime pits, as discussed by Vitruvius (1999) and subsequently (Alberti, 1460; Palladio, 1570), facilitated this process, whilst also (covered in sand or earth) preserving the lime in an 'unctuous' and cohesive state (De L'Orme, 1567), but still, largely, for use on its own - the quicklime, thrown into a pit, would be separated from the subsequent (and insulating) sand layers by wicker hurdles or similar (Hassenfratz, 1825), precisely to prevent their intermingling, and excess free water would leech away. In later centuries, similar effect was achieved by simply pressing or upon dilution after the slake was complete, as with limewash and grout - pouring the lime putty through a sieve, the lime putty (or limewash) then being used immediately, often whilst still hot (Langley, 1750; Pasley, 1826). Grout, to be poured into the core of a wall during construction, was always poured whilst hot, and as soon as practicable after slaking, in British practice, at least (Pasley, 1826). Beyond this, the purer the lime, the less likely lateslaking was (Rees, 1829), but the lumps might remain an irritation. For plastering other than finish coats, the mortars were typically hot mixed and were either used hot or were set aside for a relatively short period to allow for late-slaking. Alberti (1460) is the only author who argues that the quality of the material is 'improved' for being laid down 3 months - the general consensus was, in fact, the opposite of this - that the longer lime was laid down for, the weaker would become its binding qualities (Rees, 1829), and in the 19th and 20th centuries in the UK, the lime from such pits was typically used within two weeks, if not sooner (Copsey, 2019a, 2019c). By improved quality, of course, Alberti may simply have meant 'lump-free', especially as his discussion of the method is within the chapter on 'ornament', not construction, the lime for which, he suggests, would be used much more promptly.

\section{THE 'LIME REVIVAL'}

Whilst all of the above may be reasonably stated in the context of extensive literature and archive research carried out by the author; and of innumerable historic mortar analyses, as well as the simple observation and practical experience of many, both of these ubiquitous forms of mortar have been largely ignored by the building conservation community, as well as by the lime world' over recent decades. This same community has proclaimed a fundamental commitment to the principle of likefor-like and compatible repair, and yet has generally observed neither principle in its practice. The 'Lime Revival' began in Sweden (Holmstrom, 1996) and, shortly afterwards, in the UK, but was initially constructed upon a foundation of 'matured' lime putty as a binder, a foundation which either failed or fell from favour and which was then substantially rebuilt upon a foundation of Natural Hydraulic Lime. Putty lime, which had become more normal as a binder during the 20 thC, usually in the context of the subsequent mortar being gauged with relatively small volumes of Portland cement or gypsum, was assumed or deduced by scant or incomplete readings of historic texts, to have been the primary binder of historic mortars. It had not been. At the same time, dry hydrated lime, as well as the use of any Portland cement, was condemned out of hand, despite the significantly greater historic precedence of dry hydrated lime for use as a binder historically, especially when lime had to be carried long distances (over which distances quicklime might begin to air slake) or when quicklime on site had to be processed and stored (for similar reasons) or when a somewhat less 'sticky' mortar was demanded in use. Its method of preparation, with just sufficient water added to effect the slake, guaranteed the minimum necessary temperature of the slake, whatever the ambient temperature (Miller, 1960; Hassibi, 2009) and thereby achieved a fine particle size with maximum surface area and porosity (although less fine that that achieved by either hot mixing through to a workable mortar, the quicklime run to a thick paste just prior to mixing, or, indeed, when run to a thick, doughlike paste to be set aside for use on its own). Dry hydrate was used as a binder; it was, in best practice, run to a thick paste the day before mixing with sand, improving its fattiness. Hot mixing to a dry hydrate, to be screened along with the sand was a 
common method. Dry hydrated lime was commonly used in the making of plaster mortars in the UK, at least, during the 19thC (Nicolson, 1841), as an alternative to hot mixing of base-coats. Portland cement, whilst in no way a traditional material, was much used from the earlier 20thC onwards as a gauge to otherwise pure lime mortars. Numerous stone and brick buildings were constructed across North America and Europe (and elsewhere, of course) using 1:2:9 and even 1:1:6 mortars without apparent ill-effect and produced healthy buildings of appropriate functional performance, though such mixes were most suitable for modern, thinner-wall construction (Searle, 1935). The simple prejudice of the Lime Revival, however, born at a time when cement-lime mortars themselves were being increasingly displaced by cement-sand mortars, along with the common failure in use of lime putty mortars mixed at 1 part lime putty to three parts sand, embraced a 'natural cement-lime' (Searle, 1935) binder, more normally termed a 'natural hydraulic lime'; putty lime mortars fell increasingly from use and had, anyway, never been a 'mainstream' material beyond conservation use, except when gauged with Portland cement during the earlier 20thC. Having been more used for ordinary works in the UK in the early 20thC and then rejected for such use (Mitchell, 1912, 1947), in the light of experience and because cement-lime mortars were seen as more reliable and constant, Natural Hydraulic Lime (NHL) mortars became the 'new normal' for conservation and for some new build construction. It is important to say that this shift, from the later 1990s, towards general NHL use was not at all founded upon prior research (Ashurst, 1997), neither into the historic use of these materials nor, indeed, into their nature or actual performance. Natural Hydraulic limes were given equivalence of performance with fat lime: pozzolanic hydraulic limes historically when no such equivalence may reliably be said to exist (Jefferson, 2014). In the absence of such analysis, the general hear-say and 'telephone whispers' of the Lime Revival held sway, NHLs had 'always' been used (in fact, hydraulic lime mortars, made with pure or nearly pure lime and pozzolanic aggregates, such as volcanic ash or brick had long been used, in particular situations, such as underground or underwater, places where fat lime would not carbonate or set hard); NHLs had 'always been used in France', for all normal building (Ashurst, 1997). In fact, earth-lime mortars, as well as hot mixed fat lime mortars, had been the primary mortars of construction above ground in France, as everywhere else, and more recently than in the UK. These, and numerous other, assertions made in favour of NHL-use (as well as against fat limes) over the last two decades rarely, if ever, stand up to the scrutiny of observation, experience, mortar analysis, a deeper reading of historic texts on the manipulation or use of lime mortars, or, indeed, broad surveys of primary archive material, building accounts in particular (Copsey, 2019a, 2019b, 2019c).

Certainly, from the earlier 19thC onwards, engineers, and particularly military engineers, lobbied for the use of hydraulic limes 'in the air', above ground. Vicat (1818) led the charge in this regard and was oft-quoted in support of the shift towards NHL-use. It is important to note, however, that even Vicat did not promote the use of NHLs, and distrusted these as much as he did fat limes, encouraging rather the use of his own patented artificial hydraulic lime, manufactured in a factory he had built on the outskirts of Paris (Vicat, 1818; Treussart, 1842). Others followed his lead, seduced into the belief that the use of hydraulic materials above ground would deliver greater longevity to their buildings. Masons and other crafts continued to disagree, and for so long as they retained their autonomy in the matter of mortar-design, they continued to use fat lime mortars, with or without small volume additions of pozzolan, such as wood ash, forge ashes or brick dust.
In the ordinary constructions, we prefer to employ fat limes and sand to gather stones and to build walls because this mortar is abundant and cheaper. In humid places, in particular underwater, wherever we wish to stop the action and infiltration of water we use a mortar that hardens underwater or we use some 'béton'. (Hassenfratz, 1825, p. 368)

Still, in the early 20thC, Champly in France set out a hierarchy of mortar use that may be seen to be representative of all previous space and time, the proviso being only that the 'slow' (Portland) and 'prompt' (Natural) cements he mentions, were made - before the discovery of either, by other means in the past for the purpose, with fat lime and pozzolans, with rosin, pitch or other 'cements' known over millennia to work in the situation.

We differentiate mortars thus: fat lime, used for raising walls, hydraulic lime for foundations, substructures, basement and works meant to be immersed. Slow or prompt cement for underwater works or in very humid places. (Champly, 1910, p. 54)

John Smeaton had been instrumental in the deployment of Blue Lias NHL for water works, a material significantly higher in free lime than modern NHLs, as is indicated by his use of a mortar of one part dry-hydrated Blue Lias lime to 1 part Italian pozzolan upon the Eddystone Lighthouse - but generally - and in common with most British engineers at this time (and still well into the 19thC) used fat lime and trass (or wood ash, or calcined ironstone dust, or simply coal ash) for waterworks and accepted that craft practice and its preference for fat limes was legitimate and understandable in the context of above-ground construction their being the cheapest in terms of raw materials and the most efficiently prepared and deployed and - contributing to this - as having the greatest sand carrying capacity, further reducing cost.

It is not to be wondered at that workmen generally prefer the more pure limes for building in the air, because being unmixed with any uncalcareous matter, they fall into the finest powder, and make the finest paste, which will of course receive the greatest quantity of sand (generally the cheaper material) into its composition, without losing its toughness beyond a certain degree, and requires the least labour to bring it to the desired consistence; hence mortar made of such lime is the least expensive; and in dry work the difference of hardness, compared with others, is less apparent. (Smeaton, 1791, p. 108)

\section{MORTAR PROPORTION}

The consensus of masons and other crafts historically, as evidenced not only by surviving texts, but by material science, is that the maximum amount of sand that might be put to 1 part of quicklime was 3 parts; and oftentimes, 2 parts. A pure quicklime will more or less double in volume as it slakes, delivering on analysis a final lime:aggregate proportion of 1:1.5, when mixed at 1:3 quicklime. Simple acid-digestion analysis will include any residual lime lumps in this equation (as well as any limestone addition). With these excluded from the calculation, the most common binder: aggregate proportion is $1: 2$, sometimes $1: 1$; whenever slaked lime is specified historically this tends to be at $1: 2$. Lime mortars were frequently richer in lime than this, and pure lime pointing mortars over earth or earth-lime built fabric in North Yorkshire tended to be 2:1 lime to aggregate. A haired plaster mortar over earth-lime backing from Malton was recently analysed as containing only $10 \%$ limestone aggregate, the rest comprising lime and hair (Revie, 2019). Neve (1726) indicates 6:1 lime to ox-hair. Some of the bricklaying mortars in London, 
detailed in the 1750s (Langley, 1750) would have been as limerich as 4:1 lime to sand. A common slaked lime proportion in earth-lime mortars is 1:5 (Rondelet, 1803), although, depending upon the clay content, the addition of lime might be thought unnecessary. Around $10 \%$ lime addition was common. The recommended appropriate and necessary proportion of lime and sand or other aggregate during the 'lime revival' represents its fundamental error and led to a cascade of other related errors. Earth-lime mortars were always relatively lime-lean, a little lime goes a long way in combination with clays. Robert Boynton (1980), writing in the context of soil stabilisation, lists out the potential effects of low level lime addition: as much as a threefold decrease in the plasticity of the soil; an increase in the plastic limit and a decrease in the liquid limit of the soil; much reduced shrinkage and swell; a potentially dramatic increase in unconfined compressive strength, up to forty-fold depending upon the type of clay, and a consequent increase in load-bearing capacity; an enhanced water-shedding capacity, all of which offer benefit to the builder, as well as to built fabric. However, when lime was mixed with sand or other aggregates (whether these were inert or reactive) it was always in relatively high proportion. Pasley in 1826, in common with engineers elsewhere, and particularly motivated by the reputation of London brickmasons for wanting very lime rich mortars (such as 4:1), a preference possibly driven by the inefficiency of its delivery to site, as well as by its general transport by water from some distance away, leading to significant air slaking before use (Davy, 1839; Gwilt, 1839), set out to discover by experiment the ideal parameters of lime: sand proportion. His conclusion was that the most sand that might be put to one part of air quicklime without compromising workability and performance was 3 parts; the least sand, 2 parts.

It is surprising, therefore, that the lime revival elected to adhere to a slaked lime: aggregate proportion of 1:3 - adding at least half as much lime to 3 parts of sand as had ever been the practice before; reflecting only the fact that when cement-lime mortars became the norm, the binder: aggregate proportion became 1:3 - allowed, one might say, by the additional power of the cement component $(1: 3: 12$; $1: 2: 9 ; 1: 1: 6)$. In the case of lime putty, the volume of even the densest lime putty might comprise $30 \%$ free water (Boynton, 1980), so that to mix this at a struck gauge of 1:3 (which most did) would deliver a mortar more like 1 slaked lime: 4 sand - less lime again.

A lime putty made to traditional prescription - the water added to the quicklime in 'just sufficient' quantities to effect the slake to either a dry or a dough-like mortar consistency, any further dilution coming after the slake was complete - or even to the prescription of the 1951 British Standard Code of Conduct, with lump lime added to a given volume of water in a roughly 1:2 proportion (reflecting traditional slaking water volumes historically when more than a dry hydrate was demanded), will deliver a dough-like material which is mouldable, water retentive, cohesive and adhesive - in character, much like the linseed oil putty from which the term is almost certainly derived. Whether for use as a mortar, a grout or a limewash, these slaking methods deliver a material of appropriate tenacity as well as one that might be readily mixed with sand, if need be, at a 1:2 proportion. Few modern, commercially produced lime putties display these qualities, or may be so mixed without producing a slurry - they have been drowned. A lime putty made this way and mixed to a traditional proportion will be a useful and durable material, although one that may be less efficiently prepared and lacking in some specifically useful qualities when compared to a hot mixed lime mortar, lest the putty be mixed directly with sand whilst still hot. Mixed at 1 part to 3 or 4 , however, it did not always deliver durability and its routine failure in the hands of masons and builders no longer used to the use of straight (or any) fat lime mortars led ineluctably to the uncritical embrace of NHLs, in the UK, and then to the increasing creep of these 'conservation' materials across the world and, indeed, into parts of the world where no readily accessible hydraulic limestones had ever existed, such as the USA and Canada. Blue Lias lime had been imported into New York City and into Ottawa during the 19thC, but to be used in the making of concretes for footings or floors, not for use above ground (Fuller, Jones, 1849), the same uses, indeed, for which it had been used in the UK after 1815 uses for which NHL may be seen to be the only ones for which it was preferred. For all that Blue Lias lime was by then readily available, the river walls at the British Houses of Parliament were bound in 1847 with a mortar composed of 1 part feebly hydraulic quicklime; three parts Thames river sand: 1 part Italian pozzolan, hot mixed (Barry in Accounts \& Papers (1847)), and trass was the most commonly used pozzolan across the UK in most periods after the 16thC, as evidenced by building accounts, initially used as the entire aggregate and - after Smeaton - as one-third part of the aggregate. Unlike an NHL, a pozzolanic mortar retains excellent workability.

\section{RECENT TECHNICAL RESEARCH}

Does the increasing prevalence of NHL-use - offered credence by its now routine use for conservation in the UK, perhaps erroneously seen internationally as being somewhat 'ahead of the game' matter? Is it as compatible with porous building fabric as has been generally asserted, for all that it was little-used and widely distrusted historically, even, in fact, for underwater use (Wright, 1845; Treussart, 1842)? Wherein lies its authenticity?

Although we give to this compound the name of hydraulic lime, it ought, in fact, to be regarded as a substance altogether different from lime; it is a new body with new properties' (Treussart, 1842, p. 107).

The use of Natural Hydraulic Lime (NHL) has become extremely common in conservation work in recent years. The reasons for this are unclear, although a complete ignorance of what the material consists of, coupled with hard selling by the manufacturers, are probably the two main factors. (Jefferson, 2014, p. 1).

After extensive practical testing, Treussart concluded, along with others (Wright, 1845), that a pozzolanic fat lime mortar performed better and more reliably than an NHL for use in water works; Jefferson predicted from the chemistry alone of modern NHLs as displayed by X-Ray Defraction that variability of mineralogy between and within the same sources was likely to produce materials of inherent variability of performance, as well as identifying the presence of alite, inert fillers and even gypsum in some of the NHLs examined. Inherent variability was very well known historically and this was clearly demonstrated by the testing of currently available NHLs in the laboratory over a three year period (Figueiredo, 2018).

Unknowingly reflecting the preferences of their peers in the past, most masons or conservators who had used fat lime mortars previously, had tended to dislike NHL mortars. Those who had previously used cement (but not cement-lime) mortars have been more open to their use. Most builders required by statutory bodies, taking their lead from Historic England after 1997 - such as National Parks - to use NHLs, or some who have been persuaded that they are the right thing to use - tend to dislike them, finding them little workable and inherently variable - setting at different rates from one bag or batch to the next. This translates into variable strength development and such will be distrusted by any builder. 
Unquestionably, the widespread acceptance of NHL in the UK and beyond has rendered the requirement to use 'lime' more widely observed. It has also lowered the skill threshold of those working with lime. There are very many conservation professionals and practitioners in the UK today who have never used a fat lime mortar, and who are therefore unused to its typical behaviours, such as initial shrinkage, and who equate such shrinkage (easily dealt with when the mortar remains plastic and then most unlikely to reappear, the opposite of hydraulic materials, which do not obviously shrink initially but which may shrink up to 4 times as much in their lifetimes, but after the mortar has set hard (National Lime Association US, 1934), with defectiveness or deficiency. NHL, like Portland cement, seems to tolerate bad practice and poor workmanship in the area of joint preparation and aftercare, allowing these to be ignored for reasons of 'economy' without immediately obvious ill-effect. It has become increasingly common in the UK, particularly where companies are large, and the contracts won by competitive tender largely irrespective of experience or track record, for no wetting of substrates to occur and for no on-going hydration to be delivered to placed NHL mortars, just as the same has occurred when cement mortars are used, also contrary to best practice. In both cases, this ignores not only the demands and nature of the material, which requires ample wetting of substrates (or of stones or bricks to be laid) and on-going hydration (every day, several times a day) of placed mortars over as long a period as possible (although most guidelines suggest only 7 days), and certainly over the period of maximum strength-gain, which for cement is 28 days and for NHLs, 180 days. This is not simply to counter-act the tendency for overly lean lime mortars (such as putty or NHL mixed at historically unprecedented proportions of 1 part slaked lime to 3) to dry out too quickly, (due to their poor water retentivity), leading to a loss of necessary tenacity and bond, but in order to feed the on-going development of the hydraulic set and, in particular, the long-term strength development of di-calcium and tri-calcium slicates (belite and alite respectively), both of which are present in Portland cement and both of which, contrary to historic prescription (Davy, 1802; Eckel, 1922; Geeson, 1952), are present in all but a few of currently available NHLs (Jefferson, 2014; Figueiredo, 2018). Compared with natural cements, which contain belite, but no alite and no free lime, but which are otherwise comparable to NHLs, these are understood to require on-going hydration for the six month period of their greatest strength-gain and will continue to gain strength for at least 10 years (Vicat Ind. Tech. Data). Until recently, no sense of the likely on-going strength development of NHLs was expressed, or even understood, with only one company (St. Astier) offering data about 2 year strengths of mortars made with their material.

Figueiredo's research also demonstrates what was always known historically, that NHLs are perennially variable in strength not only between brands, but also within these. The first call to prohibit their use on this basis was made by Le Sage in France in 1777; it was acknowledged thereafter by numerous sources, including by Boynton in 1980:

A major problem confronting most hydraulic lime manufacturers is lack of uniformity in the finished product, namely, shipping a lime with a Cementation Index of 0.92 one day, 0.70 the next, and so on. The chemical analyses in impure deposits frequently change abruptly from one ledge and stratum to another. Blending of stone to secure a composite analysis alleviates this problem to some extent but can never be pursued with the same flexibility available in Portland cement plants. Furthermore, the intensive analytical testing that it entails is costly. This chronic problem of quality control, more than any other factor, has forced hydraulic lime to lose position primarily to Portland cement and masonry cement. (p. 315).
The NHL research points up the complete inadequacy of the European Standard, which allows for any designation of NHL (2, 3.5 and 5.0) to be up to 3 times stronger after 28 days than the minimum requirement in each category, without breaching the standard. The minimum strength after 28 days of an NHL 2.0 is also the maximum strength required after 28 days for a feebly hydraulic lime under the 1966 British Standard (Henry et al., 2018), the minimum being around 0.8 of an MPa over the same time period reflecting the typical strengths of air lime and truly feebly hydraulic limes used in the UK historically. Although the greatest strength development of NHLs is during the first 6 months, strength-gain continues at a steady level thereafter. Between 6 months and three years, the curve of strength-gain, whilst significantly lower, remained constant. The maximum strength and the maximum period of this steady, incremental strength gain is unknown. Each gain in compressive strength in an hydraulic material generally equates to a reduction in porosity and progressive densification of pore structure. A cement-lime mortar tested under the same regime - as well as fat lime mortars made with 5 and with $10 \%$ addition of meta-kaolin - reached maximum strength after 3 months. As an indication of variability within 'brands' 2 bags of the same NHL with the same strength designation were purchased in different parts of the UK on the same day; two mortars were made and each was tested in two laboratories. One delivered a mortar $30 \%$ stronger than the other. To build an elevation in which the mortars might display such variation in compressive strength would seem to be a recipe for structural compromise and at least localised failure. All mortars were mixed by volume and at a more traditional proportion of 1:2, unlike in the Standard. Beyond this, not a single item of technical data offered upon any of the NHL producers' or suppliers' web-sites was borne out on test, making the specific properties of these materials essentially unknowable, especially as they may anyway be routinely variable from one batch of NHL to the next. Of as much concern is that in a number of cases, the NHL 2.0 mortars had a greater compressive strength on test than either the 3.5 or the 5.0 from the same sources. The strongest mortar on test, and throughout the three-year period of the test regime, was an NHL 3.5. The lowest strength mortar on test was also an NHL 3.5, and was almost a third of the strength of the hardest. None of the strengths break the European Standard, indicating clearly that this Standard may not be seen as useful to either specifiers or users of the material: the Standard may not be seen as fit for purpose in the context of either conservation or, indeed, new build (Henry et al., 2018).

\section{EFFECTIVE POROSITY}

David Wiggins demonstrates very clearly that - in the case of traditional, binder-rich, typically hot mixed lime: sand mortars carbonated air lime is the key to their high capillarity and, therefore, to their breathability. In the same vein as the US Bureau of Standards concluded that the more free lime that was contained by a cement-lime mortar the better bond and extent of bond, the better water retentivity and workability it possessed, Wiggins concludes that the more free lime in a mortar, the more effectively porous it will be; the more capillary active, so that effective porosity is in large part a function of calcium carbonate formation. By extension, the ability to quickly dispose of received moisture makes such mortars frost resilient, as well as generally ensuring that the mortar joints are more effectively porous than the masonry units and will gather damaging salts, preventing salt-induced decay to the masonry itself and behaving sacrificially. High capillarity within an inter-connected pores structure is fundamental - and is the real definition of 'breathability'. Vapour permeability, which NHLs and cements display in laboratories, is NOT breathability; nor, necessarily, is laboratory demonstrated porosity, per se. Vapour permeability or diffusion is a slow and inefficient mechanism for drying out 
porous fabric (Pender, 2017), especially in the general absence of capillarity, and may be considered effective only in very thin sections. Most NHLs, however, are promoted on the basis of their inherently low free lime content and their low capillarity (St. Astier website).

Most 'value-added' NHL-based pre-mixed mortars also contain additives, such as chemical air entrainer, water repellent or even latex (Masons Mortar Technical data, 2019). There is no legal requirement to declare the presence of such additives. In the 1920s and 1930s the US Bureau of Standards demonstrated that the addition of air entrainer (which will improve workability in a poorly workable mortar, as well as improving theoretical frost resistance) will compromise the bond between mortar and building units, as well as the extent of bond, both of which are already poor when a hydraulic material with minimal free lime (and consequent low water retentivity) is used (Palmer, 1934). Wiggins goes further than this to demonstrate that the addition of either air entrainer (soaps, such as sodium sulphonate) or water repellent (typically stearates derived from fats, such as tallow or linseed oil) will eliminate capillarity and leave the mortars with a bare minimum of effective porosity, for all that their vapour permeability might increase (Torney, 2016). 'Breathability' as a useful term has come over recent years to mean 'vapour permeability' and a host of products on the market proclaim their breathability on this basis. Without high capillarity as well, such products may not be reasonably called breathable at all and the consequences for historic fabric of this market-driven confusion are frequently, if not, indeed, generally negative, especially when the stone of construction is limestone, calcium carbonate, and is itself strongly capillary-active, so that the application of a mortar of lesser capillarity will encourage inevitable sacrificial behaviour in the limestone:

The Bath freestone is of the pure calcareous kind, and it is remarked that when it is walled with this kind of mortar (blue lias), which is frequently, if not generally, used for the purpose, the joints are more permanent, and resist the weather better, than the stone itself... (Smeaton, 1791, p. 115)

Similarly great concern might be expressed whenever NHLs are used in association with earth or earth-lime structures, given the inherent compatibility in the functional behaviour of earth, earth-lime and hot mixed lime mortars in terms of their pore size distributions and capillarity. More importantly, an earth-lime mortar exhibits a similar pore size distribution to a lime-rich air lime mortar, offering a similar level of capillarity. The covering of an earth-lime mortar, whether in the form of a building mortar, adobe or rammed earth (both of which commonly contained added lime and/or naturally occurring calcareous aggregates (Vegas et al., 2014). A mortar of lesser capillarity will inevitably compromise the proper performance of such effectively porous substrates. It will be incompatible.

\section{OBSERVED PERFORMANCE OF NHLS IN THE UK}

In the UK, where NHL mortars have been extensively used since John Ashurst of English Heritage gave the green light in 1997, simple observation indicates that the buildings upon which these mortars have been used have tended to become excessively wet; wherever salts are in the equation, even reputably very durable (but porous) stones and bricks have suffered accelerated decay, whilst the mortars themselves have displayed no sacrificial behaviour. In cases where previous fat lime, or even cement-lime, mortars have been removed in favour of NHLs, buildings that had been essentially dry and healthy have become wet and unhealthy; salts appear for the first time upon (and within) the stones, particularly when these are of limestone geology or are of porous sandstone. Mass earth structures have some of them collapsed as the accumulation of liquid water reaches critical levels. In contrast to this, buildings repointed or repaired with lime rich, typically these days hot mixed, lime mortars, rapidly dry and remain dry, raising their thermal performance, and defending stones and embedded timbers from normal decay mechanisms, such as frost or salt activity. After 15 years of use in some parts of the country, coincidentally those parts where lime-lean lime putty mortars struggled or failed, in the North of England and in Scotland, hot mixed air lime mortars, as well as hot mixed feebly hydraulic lime mortars (gauged with either pozzolans or, indeed, with NHLs, as commonly in Scotland) have proved to be durable and generally resilient and have promoted the drying of traditional fabric. They are like-for-like and they are inherently compatible, whether the substrate is of earth, earth-lime or lime: sand or other inert aggregate. These mortars are cost-effective and efficient to produce, eminently workable (encouraging good workmanship), cohesive, adhesive and eminently water retentive, all but ensuring good and effective bond, as well as a high level of effective porosity.

\section{CRAFT PREFERENCE}

Stonemasons and other crafts chose to use pure or nearly pure quicklime because of their relative cheapness and their relatively universal availability and basic similarity across the world. Their chemical purity meant that their behaviour was generally the same and predictable and their modification - with small measures of pozzolan, for example - was also readily controlled and predictable, and did not diminish workability. A pure or nearly pure quicklime will slake immediately upon receipt of water - the more hydraulic the lime, the slower this reaction will become, and even a feebly hydraulic quicklime will be somewhat slower to begin slaking, the slake taking longer to complete. An eminently hydraulic quicklime may take 12 hours to react at all, and up to 36 hours for its free lime content to substantially slake. The slake of a pure quicklime will take around 2 minutes, after which time-span, the sand may be mixed with it to immediately make a useable mortar. The hot mixing method delivers a mortar which exhibits no free water, building with it incurs no likelihood of 'swimming stones' (McAfee, 2000) (their movement lubricated by free water emerging from the mortar) and a much-reduced risk of staining. The excellent water retentivity of lime rich mortars (of any kind) mean that aside from the wetting of substrates to control (but by no means to kill) suction (from porous building units, as well as from porous existing mortars of construction), no further wetting of the placed mortars is either necessary or desirable, this will only delay or prevent the on-set of carbonation at the surface. This high water retentivity also means that protection from over-rapid drying out of the curing mortars is generally (although not always) unnecessary, reducing labour-time, although the tops of walls under construction will always require protection (which was frequently of thatch, historically) to prevent the ingress of water before copings or other weathering details are in place.

Such absence of on-going hydration or protection in a hydraulic material will compromise its set and leave it without necessary tenacity (Vicat, 1818; Sutcliffe, 1899). In extreme cases, although this has been commonly observed in the UK, an apparently sound NHL mortar at its face will be either powder or mush within the wall, one of the reasons NHL mortars seem to lead to the cumulative wetting up of traditional fabric, along with the progressive diminishment of their effective porosity as the hydraulic set develops and their tendency to shrink away from building units after hardening and as the long-term silica set develops. A further practical consideration, when NHL mortars were made from hydraulic quicklime on site, as they still were by preference in the UK as late as the 1951 British Standard, was that the addition of slaking water in excess of that necessary to 
slake the free lime content would initiate the hydraulic set, whilst only those NHLs with a high free lime content might be slaked and mixed through to a mortar immediately, albeit most often for concrete. How was it possible to know how much free lime there was in the quicklime of any particular batch? Some hydraulic set during the required period of repose, would be almost inevitable, weakening the final product. At the same time, alite clinker ('grappiers') present amidst the lump lime could be (and was) removed by the masons before or during slaking. Modern production methods mean that this clinker is ground to a fine (and therefore reactive) powder before slaking, meaning that modern NHLs are likely stronger in use than historically, even had they been used above ground much at all. Geeson (1952) says that NHLs processed in this way might be more precisely termed 'natural cement', but with sufficient non-hydraulic quicklime present to avoid the cost of mechanical grinding, sufficient for all to fall to a powder unassisted (Eckel, 1922).

Historically, masons and other crafts did not proclaim the 'breathability' or otherwise of their mortars - they used earthlime and hot mixed lime mortars for the reasons above, not explicitly because of their 'breathability'. However, they knew from long experience that these materials delivered dry and healthy fabric. Alberti proclaimed the health benefits of earth buildings in 1460 and similar sentiments were expressed by architects and others in 19th and 20thC France and the UK, who saw earth building as a cost-effective means of housing the rural poor (Cointeraux, 1790; Champly, 1910; Doyle, 1844; Loudon, 1846; Scott Burn, 1860; Bruce Allen, 1886).

\section{CONCLUSION}

The universal system of traditional building - solid wall construction using generally porous and hygroscopic materials, the masonry elements then covered with similarly porous renders and limewashes, providing the general fabric with a high-capillarity overcoat - worked, and worked well. If it is to continue to work, or to regain proper performance and to work once more as its builders intended (Oxley, 2003), best practice conservation - in keeping at last with its primary principles of like-for-like and compatible repair - and in eschewing essentially modern materials the consequences of which cannot be immediately known; the ingredients of which, in the case of may NHL-based pre-mixes, are not known and need not be advertised under current standards (another conservation principle), we need to be using the same or similar materials they did, processed in the same or similar ways and used to the same or similar ends, and at the same time that academic and other scientific research endeavours - at last - to make sense of the reasons traditional buildings work and the ways in which the same or similar technology might be adapted and adopted in the ever-more urgent struggle to combat climate chaos, in terms not only of regaining proper performance in our stock of traditional buildings, but in sustainable new build.

\section{REFERENCES}

Accounts \& Papers, Post Office; Public Works \& Buildings; Shipping Vol 22. 1847-1848. Returns \& Contracts Relative to the New Houses of Parliament. London. House of Commons.

Ashurst, J., 1997. The Technology and Use of Hydraulic Lime. Building Conservation Directory. Cathedral Communications. Also Lime News 1997 Vol 5.

Biston, V., 1828. Manuel Théorique et Pratique du Chaufournier. Paris, Roret. Translated by Michel, E., 2017.
Boynton, R. S., 1980. Chemistry and Technology of Lime and Limestone. New York, John Wiley \& Sons.

British Standards Institute, 1951. British Standard Code of Practice 121-201. London, British Standards Institute.

Bruce Allen, C.,1886. Cottage Building, or Hints for Improving the Dwellings... Lockwood and Co.

Champly, R., 1910-1914. Nouvelle encyclopédie pratique du bâtiment et de l'habitation, Volume 2. Paris, H. Desforges.

Cointeraux, F., 1790. Rural school of architecture or lessons from which we will learn... Paris, Chez l'Auteur.

Copsey, N., 2019a. Hot Mixed Lime and Traditional Mortars. Malmesbury. Crowood Press.

Copsey, N., 2019b. Tech. Paper 30. Historic Literature Review of Tradit.Mortars. Edinburgh, Historic Environment Scotland

Copsey, N., 2019c. A Critical Review of Historic Literature Concerning Traditional Lime and Earth-Lime Mortars. MA (by research), University of York.

Davy, H., 1802. Elements of Agricultural Chemistry, etc. London. Longman, Rees, Orme, Brown, Green \& Longman

Davy, C., 1839. The architect, engineer, and operative builder's constructive manual..., $2^{\text {nd }}$ Ed. London, J.Williams.

De L'Orme, P., 1567. The first book of architecture. Paris, Frederic Morel. Translated by Emma Michel 2018.

Eckel Edwin. C., 1922. Cements Limes and Plasters... New York, John Wiley \& sons; London, Chapman \& Hall. 2nd ed. Reprinted by Forgotten Books.

Eires, R., Camoes, A., Jalili, S., 2013. Earth Architecture: ancient and new methods for durability improvement. Cruz (Ed.) Structures and Architecture. Taylor \& Francis

Faria, P., 2016. Argamassas de terra e cal - caracteristicas e campos de aplicacao. Jornadas Fical. Forum Iberico da Cal.

Figueiredo, C., 2018. Properties and Performance of Lime Mortars for Conservation. PhD Thesis. University of Bath.

Fuller, T., Jones, C., 1859. Contract and Specifications for the Parliament Buildings Ottawa (Toronto Public Library).

Geeson, A.G.,1952. Building Science Materials for Students of Architecture \& Building Vol.II. Eng. Univ. Press London

Gillmore, Q.A., 1864-1886, writ.1861. Practical Treatise on Limes, Hydraulic Cements \& Mortars; N.York: V. Nostrand

Gwil,t J., 1839. Rudiments of architecture, practical and theoretical. London, Priestley and Weale.

Hassenfratz, M., 1825. Traité théorique et pratique de l'art de calciner la pierre calcaire et de fabriquer toutes sortes de mortiers. Paris, Huzard. Translation, Michel E 2016.

Hassibi, M., 2009. Factors Affecting The Quality of Quicklime. Chemco Systems LP. 
Henry A, Holmes S, Figueiredo C., 2018. Hydraulic Lime Production Coming Full Circle?. Building Conservation Directory, Cathedral Communicat.

Holmstrom, I., 1996. The Use of Lime. Part 1 The General Use of Lime in Sweden. Lime News Vol 4 Nol.

Jacques, D. H., 1860. RuraI Architecture: Or, How to Build Country Houses \& Out-Buildings. N.York. Fowler \& Wells.

Jefferson, D., 2014. What is NHL? Does it have a role in conservation? www.hotmixedmortars.com.

Johnson, H. V., 1926. Cement-Lime Mortars Technologic Papers of the Bureau of Standards No. 306. Washington Government Printing Office.

Langley, B., 1750. London Prices of Bricklayers' Materials and Works Both of New Buildings and Repairs, Justly Ascertained. London Richard Adams 2nd Edition.

Loudon, J. C., 1846. Edited by Loudon J W. An Encyclopaedia of Cottage, Farm and Villa Architecture and Furniture. London Longman, Brown, Green and Longmans.

McAfee, P., 2000. Swimming Stones. Traditional Masonry Journal. Chicago, US Heritage Group.

Minke, G., 2006. Building with Earth. Basel, Birkhauser.

Miller, T., 1960. A Study of the Reaction Between Calcium Oxide and Water. National Lime Assoc., Washington, USA

Mitchell, C.F., 1912. Building Construction. Seventh edition, thoroughly revised and much enlarged. London, Batsford.

Mitchell. C.F., 1947. Building Construction. Batsford, London

National Lime Association (USA), 1934. Masonry Mortar, Bulletin 321.Washington DC.

Neve, R., 1726. The City and Country Purchaser. Whitstable David and Charles (1969)

Nicholson. P., 1841. Practical Masonry, Bricklaying \& Plastering 'Pract.Builder \& Mathematician'. London, T.Kelly

Oxley, R., 2003. Survey and Repair of Traditional Buildings, a Sustainable Approach. Shaftesbury, Donhead.

Palladio, A., 1570. The Four Books of Architecture (Ware translation, 1738) Dover Press.

Palmer, L.A., Parsons, D., 1934. Study of Mortars and Bricks and Their Relation to Bond. Res.Paper RP683, Bureau of St. Journal of Research. Washington DC. US Dep. Commerce.

Pasley, C.W., 1826. Practical Architecture. Repr.Royal Engineer Establ., Chatham. Repr. Shaftesbury. Donhead Pub. 2001.

Pender, R., 2017. Water in Permeable Building Materials. Building Conservation Directory. Cathedral Publications.

Powell, C. G., 1980. An Economic History of the British Building Industry 1815-1979. London, Methuen \& Co.
Rashmi, S., Jagadish, K. S.; Nethravathi, S., 2014. Stabilized Mud Mortar. IJRET Vol 03, Special Issue.

Rees, A., 1829. The Cyclopedia or Universal Dictionary of Arts, Sciences and Literature Vol XXXIII. London Longman et al.

Revie, W., 2019. Mortar Analysis of plaster, Old York House M/2013/19/Cl. Construction Materials Consultants Ltd. www.hotmixedmortars.com

RIBA Committee, 1946. The Architectural Use of Building Materials. Post-War Building Studies No.18. London, HMSO for the Ministry of Works.

Rondelet, J., 1803. Theoretical and Practical Treatise on the Art of Building. Paris. Chez Lauteur. Transl. E Michel 2018

Sage, M., 1777. Elements de Mineralogie Docimastique. Volume 1. Paris, Royal Printers.

Santos, T., Faria, P., 2016. Evaluating Earth Mortars for Rendering. Proceedings Terra Lyon 2016.

Shi-bing, D., 2013. Building Limes for Cultural Heritage Conservation in China. Heritage Science Journal.

Shi-bing, D., Hongsong, L., 2019. Conservación y mantenimiento de la tapia de la muralla histórica de Pingyao, China. Loggia, Arquitectura \& Restauración, [S.1.], n. 32, p. 46-59

Scott Burn, R., 1860. Handbook of the Mechanical Arts.. Edinburgh \& London, William Blackwood and Sons.

Searle, A. B., 1935. Limestone and its Products. London, Ernest Benn Ltd.

Smeaton, J., 1791. A Narrative of the building and a description of the construction of the Edystone Lighthouse with stone, etc. Nicol London.

Sutcliffe, G. L. (ed.), 1899. The Principles and Practice of Modern House Construction Vol 1. Blackie, London

Torney, C., 2016. Lime Mortars for High Exposure Levels. Building Conservation Directory. Tisbury. Cathedral Communications.

Treussart, C., 1842. Essays on Hydraulic and Common Mortars and on Lime-Burning, etc. Col.of Engineers. N. York; Wiley \& Putnam

Vicat, L. J., 1818. Recherches Experimentales sur Les Chaux de Construction, les Betons et les Mortiers Ordinaires. Paris, Goujon. Translation Michel E 2016.

Vitruvius, 1999. Ten Books on Architecture. Transl. by Rowland; eds Rowland ID \& Howe TN. Cambridge Univ. P.

Vegas, F., Mileto, C., Cristini, V., García-Soriano, L., 2014. La Tapia en la Pen. Iberica. Valencia, Argumentum, TC Cuadernos

Wiggins, D., 2019. Functional Performance of Traditional Lime Mortar in Copsey (2019) Hot Mixed Lime and Traditional Mortars. Malmesbury, Crowood Press.

Wright, W.H., 1845. A Brief Practical Treatise; Mortars: An Account of the Processes Employed at the Public Works in Boston Harbor. Boston, Ticknor \& Company. 